\title{
The North Korean Economy: \\ Current Situation, Crisis, and Possible Scenarios
}

\author{
SEOK-HYANG KIM ${ }^{*}$
}

For more than a half century, the international community largely ignored North Korea. Since 1990, however, the situation has changed dramatically and North Korea has begun to attract increasing international attention. Throughout the 1990s, scenarios of a North Korean collapse were in vogue. Yet, these estimations were proved to be wrong. It is now widely accepted that North Korea is relatively stable in the sense that it seems to have little trouble keeping its political system intact and functioning. By now, the most striking aspect of the North Korean political system is its extraordinary resilience. Why then has the North not yet collapsed, despite the chronic shortages of food, energy, and foreign currency?

In this paper, I would like to raise two main questions. The first question is: "How serious are the difficulties of the North Korean economy?" And the second is: "What actions has the North Korean regime taken to resolve these difficulties and how effective those actions have been?"

The North Korean regime has been striving to readjust and improve its economic structure since the 1970 s. The regime has sought foreign capital and technology. However, the regime has been attempting to reformulate its economic structure within the strict framework of the existing political system whose survival was its paramount concern, and therefore it has failed to link the domestic economy with the world economy. What the regime has been doing is, on the one hand, to map out policy measures designed to open up its doors, while on the other hand escalating its ideological and political campaigns to prevent the people from being "contaminated" by a capitalist culture which it anticipated would develop as a result of such measures. It is no wonder that, under these conditions, all attempts at reforming met with only limited success at best.

The North Korean regime, however, has negotiated with its people the expansion of its second economy, despite its reluctance to do so. In fact, the regime explicitly defined farmers' markets as remnants of "backward" capitalism which would become extinct as socialism reached a higher stage of development.

It is expected that the ruling hierarchy in North Korea will be able to survive for a considerable period of time, despite the threatening economic crisis. So far in North Korea, the need to safeguard the existing political regime has been given far greater priority than the need to bring about reform. However, the North Korean regime, if it intends to survive, will be compelled to carry out full-scale reforms sooner or later.

Keywords: the North Korean economy, the North Korean political system, resilience of North Korea, economic reform of North Korea, North Korea's dilemma 


\section{WHAT QUESTIONS DO WE HAVE NOW?}

F

or more than a half century, the international community largely ignored North Korea. Since around 1990, however, the situation has changed dramatically and North Korea has begun to attract increasing international attention.

Throughout the 1990s, the international community has adopted two different approaches when dealing with North Korean issues. One is a humanitarian approach which has resulted from a general compassion for the plight of the North Korean people. North Korea is described as a place where starvation, poverty, and disease are rampant. The people of North Korea are faced with a life and death struggle, and this mandates the humanitarian effort of the international community. The other approach is based on realpolitik, and is driven by lingering concerns about a possible collapse of North Korea and its likely negative impact on the international community. Many journalists and scholars have speculated how and when North Korea is likely to collapse and proposed their own scenarios and contingency plans.

Scenarios of a North Korean collapse were in vogue and were widely discussed on at least three separate occasions. The first such occasion was the late 1980s and early 1990s. At the time, many scholars predicted that North Korea was likely to collapse in the very near future. They based these predictions on the then current disintegration of the Soviet bloc, increased economic liberalization in China and rapid political changes worldwide. Some specialists at the time confidently argued that North Korea would collapse within just one or two years, like Romania. However, these prophets were proved to be wrong.

The collapse scenario regained popularity after the death of Kim Il-sung on July 8, 1994. The death of Kim Il-sung, many experts believed, brought North Korea to the brink of an immediate collapse. Kim Il-sung, they argued, had controlled the North as an autocrat for more than 40 years. Without Kim Il-sung, their arguments went, North Korea was not likely to maintain its centripetal force. Periods varying from 3 weeks to 3 years were mentioned as the North Korean regime's life expectancy. Yet, these estimations also failed miserably. Then, in 1995 , the North Korean regime officially recognized it had a food crisis and, for the first time in its history, began to solicit international aid. ${ }^{1}$ With the official recognition of the food crisis, many scholars felt even more sure that North Korean system would collapse in the immediate future.

Then Kim Jong-il's inexplicable behavior after his father's death also stimulated the popularity of these predictions. For over three years after his father's death, Kim Jong-il ruled North Korea without officially assuming top positions in the party and the state, and many experts interpreted this as a certain sign of serious domestic instability. In October 1997, however, three years and three months after Kim Il-sung's death, Kim Jong-il assumed the position of General Secretary of the Workers' Party of Korea (WPK). In September 1998, about a year later, North Korea revised its Constitution, and Kim Jong-il also became the chairman 
of the DPRK National Defense Committee and the supreme commander of the Korean People's Army (KPA). All signs indicate that Kim Jong-il is now firmly in control of the North Korean political system (Koh 1998).

It is now widely accepted that North Korea is relatively stable in the sense that it seems to have little trouble keeping its political system intact and functioning. By now, the most striking aspect of the North Korean political system is its extraordinary resilience. Contrary to the once popular collapse scenarios, North Korea has been to sustain its social and political system up to 2005 and is now even adopting somewhat reform options. Following the adoption of the "New Thinking" policy in January 2001 (Rodong Sinmun 2001), North Korea announced the "Principles for the Enhancement of Economic Management" in October of the same year, paving the way for changes in its economic management. In addition, North Korea began implementing "Economic Management Enhancement Measures" in July 2002 while enacting and revising ordinances relating to economic reforms. In the second half of 2002, North Korea designated Shineuiju as the "Shineuiju Special Administrative District" (September 2002), while designating the "Mt. Geumgang Tourism District" (October 2002) and "Gaeseong Industrial Zone" (November 2002) as special districts in a move to expand the scope of regions which are open to the outside world (www.unikorea.go.kr). In March 2003, North Korea officially recognized markets and launched the "Foreign Currency Exchange Center" in June of the same year. In May 2003, North Korea issued "People's Life Bonds" to finance industrial investments as well as to control inflation. In September 2003, North Korea established a Tax Collection Agency and in 2004, it launched reforms in enterprises on a trial basis which empowered them to set prices for the products they produced and to grant wage increases based on profits (Kim and Choi 2005).

The question we are going to raise in this paper is why the North has not yet collapsed, despite the chronic shortages of food, energy, and foreign currency. It is not easy to explain why this should be so. There is a "proper" answer to this question: scholars and specialists have normally explained this phenomenon by citing the political peculiarities of the North Korean system. The explanation goes like this. The North Korean regime's only concern is maintaining its absolute power over the people. Its political indoctrination system thus becomes more rigid as the economic situation deteriorates. People in the North, in turn, are well trained to obey whatever order is handed down by the authorities. Under these conditions, individual discontent cannot escalate into social discontent and no organized anti-government force can emerge. The existing political system in Pyongyang, therefore, will probably remain intact - at least for some time.

This answer appears persuasive. Nonetheless, such an answer raises some more questions, namely: What efforts other than political indoctrination has the North Korean regime made to survive and strengthen its position? What efforts has the regime taken - especially in terms of the economy? Have these economic efforts 
been effective in persuading, or restraining, the North Korean people or not?

In this paper, therefore, I would like to raise two main questions. The first question is: "How serious are the difficulties of the North Korean economy?" And the second is: "What actions has the North Korean regime taken to resolve these difficulties and how effective those actions have been?"

To give an accurate answer to such questions will be enormously difficult. North Korea's society still remains highly reclusive and its political leaderdership has been sequestered from the rest of the world. Considering the most recent events in North Korea, however, it would not appear impossible for us to formulate some tentative answers to these questions. Based on these answers, this paper will attempt to make some suggestions as to what we should do about the North Korean economy.

\section{HOW BAD IS THE NORTH KOREAN ECONOMY?}

No one today seriously questions the fact that the North Korean economy is in deep trouble. The precise number of people who died during the famine has remained unknown: estimates vary between 600,000 and a million excessive deaths. ${ }^{2}$ The state sector of economy also experienced a disastrous decline: North Korean factories have been struggling to survive a management crisis stemming from resource shortages (Dong 2005: 19) and the low degree of capacity utilization (Hilpert 2003: 7).

The supply of energy also decreased dramatically in North Korea in the 1990s. North Korea has continuously suffered decrease in coal production. Coal is vital for North Korea, since for decades this country has been developing a coal based energy infrastructure which is reliant on its abundant coal deposits. Of all energy sources, coal supplies 70 percent of the North's needs, while electricity supplies 16 percent, petroleum 10 percent, and other resources 4 percent (Cho and Zang 1999, 21). During the 1990s, the North Korean Yearbook did not mention the country's actual annual output in coal production.

The following two tables show in what ways the North Korean economy in the 1990s was different from the 1970s. Table 1 shows that, during the 1970s, the North Korean economy recorded an impressive annual growth of 5-10 percent. Since 1990, however, North Korea's GNP had been declining for 9 consecutive years as shown in Table 2. Although North Korea's GNP growth rate has returned to positive territory recently, the total volume of GNP in 2003 has not regained the level it had reached in 1990.

Table 1. GNP Growth Rate in North Korea until 1990

\begin{tabular}{c|ccccc}
\hline Year & 1970 & 1975 & 1980 & 1985 & 1990 \\
\hline Real Rate of Growth (\%) & 10.2 & 5.4 & 3.8 & 2.7 & -3.7 \\
\hline
\end{tabular}


Table 2. Current GNP and GNP Growth Rate in North Korea AfTer 1990

\begin{tabular}{c|c|c}
\hline Year & Current GNP & Real Rate of Growth \\
\hline 1990 & 23.1 & -3.7 \\
1991 & 22.9 & -3.5 \\
1992 & 21.1 & -6.0 \\
1993 & 20.5 & -4.2 \\
1994 & 21.2 & -2.1 \\
1995 & 22.3 & -4.1 \\
1996 & 21.4 & -3.6 \\
1997 & 17.7 & -6.3 \\
1998 & 12.6 & -1.1 \\
1999 & 15.8 & 6.2 \\
2000 & 16.8 & 1.3 \\
2001 & 15.7 & 3.7 \\
2002 & 17.0 & 1.2 \\
2003 & 18.4 & 1.8 \\
\hline
\end{tabular}

North Korea has recently attempting to cope with the food crisis. In June 2002, North Korea enacted the "Agriculture Act," and in the following month, in July 2002, the regime announced a sweeping price reform called as "Economic Management Enhancement Measures." In January 2004 the regime implemented the Family Farming System on a trial basis as part of its program to expand agricultural reforms.

Such efforts toward reform have not yet solved the food crisis, however. There have been a temporary improvement in food supply, mainly due to substantial aid from abroad, but the general situation seems not to be much better: the energy supply remains grossly inadequate and a risk of starvation is looming, while uncontrollable hyperinflation also becaming a problem (Gey 2004).

Table 3 shows wage increases which followed the July 2002 measures whereas Table 4 shows the inflation rate after the July 2002 measures. With the July 2002 measures, the North Korean regime argued that it has found a way to add merits of the market economy to its planned economic system. In reality, however, the Table 3 and the Table 4 indicate that the regime drastically increased the consumer prices for numerous products while the wage increases were inadequate to compensate for this hike.

Then, Table 5 shows the details of North Korea's current economic situation. Compared to the 1990s, North Korea is now in a better shape as long as supply of cereals and rice is concerned, but it still has a serious shortage of fertilizer, insufficient coal productions, shortage of crude oils and electricity. In addition, many reports claim that the food crisis in North Korea is still not any better today (Amnesty International 2005; Lim 2005; Wownicoaded 2005). 
Table 3. Incomes Before and After the Price Reform of 1 July 2002 (IN NORTH KOREAN WON)

\begin{tabular}{l|r|r|r}
\hline \multirow{2}{*}{ Occupation } & \multicolumn{2}{c|}{ Income } & Increased by \\
\cline { 2 - 4 } & \multicolumn{1}{c|}{ before } & \multicolumn{1}{c}{ after } & factor of \\
\hline Senior party official & $150-200$ & $2,500-3,000$ & $15-17$ \\
Mid-ranking party official & 120 & 2,400 & 20 \\
Company manager & $250-300$ & $3,500-4,000$ & $13-14$ \\
Company employee & 140 & 1,200 & 9 \\
University lecturer & 270 & 4,000 & 15 \\
Teacher & 80 & 2,400 & 30 \\
Kindergarten teacher & 135 & 2,400 & 18 \\
Doctor & $120-250$ & $2,500-3,000$ & $12-20$ \\
Services occupations (hairdressers, waiters, etc.) & $20-60$ & $1,000-1,500$ & $25-50$ \\
1-star general & 247 & 6,670 & 27 \\
Colonel & 219 & 5,830 & 27 \\
Lieutenant Colonel & 185 & 4,610 & 25 \\
Major & 163 & 4,130 & 25 \\
Lieutenant & 95 & 2,970 & 31 \\
\hline
\end{tabular}

Table 4. State Consumer Prices Before and After the Price Reform of 1 JULY 2002 (IN NORTH KOREAN WON)

\begin{tabular}{l|c|r|r|r}
\hline \multirow{2}{*}{ Product } & \multirow{2}{*}{ Unit } & \multicolumn{2}{c|}{ Price } & \multirow{2}{*}{ Change in \% } \\
\cline { 3 - 4 } & & before & After & \\
\hline Rice & $\mathrm{kg}$ & 0.08 & 44 & 54,900 \\
Corn & $\mathrm{kg}$ & 0.06 & 24 & 39,900 \\
Beans & $\mathrm{kg}$ & 0.08 & 40 & 49,900 \\
Wheat flour & $\mathrm{kg}$ & 0.06 & 24 & 39,900 \\
Pork & $\mathrm{kg}$ & 17 & 170 & 900 \\
Chicken & $\mathrm{kg}$ & 18 & 180 & 900 \\
Herring & $\mathrm{kg}$ & 10 & 100 & 900 \\
Bean paste & $\mathrm{kg}$ & 0.20 & 17 & 8,400 \\
Soy sauce & $\mathrm{kg}$ & 0.20 & 16 & 7,900 \\
Beer & Bottle & 0.50 & 50 & 9,900 \\
Men's sports shoes & Pair & 3.5 & 180 & 5,043 \\
Television set & & 350 & 6,000 & 1,614 \\
Penicillin & Ampoule & 0.40 & 20 & 4,900 \\
Electricity & $\mathrm{kWh}$ & 0.035 & 2.1 & 5,900 \\
Diesel & Litre & 40 & 2,800 & 6,900 \\
Petroleum & Litre & 40 & 2,800 & 6,900 \\
Bus ticket (urban transport) & & 0.10 & 2 & 1,900 \\
Underground ticket & & 0.10 & 2 & 1,900 \\
Winter vest & & 25 & 2,000 & 7,900 \\
Men's suit & & 90 & 6,750 & 7,400 \\
Meals in kindergarten (infants) & Monthly & 50 & 300 & 500 \\
Cigarettes & Packet & 0.35 & 2 & 471 \\
Spectacles & & 20 & 600 & 2,900 \\
\hline SOUR: & & & & \\
\hline
\end{tabular}

SOURCE: Nam Sung-Wook/Gong Sung-Young, The effects of the price and wage increases of 2002 on production and consumption, unpublished mapusctiptele BP from $25-26_{i}$ il.come4/26/2023 10:06:57 AM 
TABle 5. Major ECONOMics Indicators of North Korea

\begin{tabular}{l|r|r|r|r|r|r|r|r}
\hline \multicolumn{7}{c}{ Major Economics Indicators of North } \\
\hline & & 1990 & 1995 & 2000 & 2001 & 2002 & 2003 & 2004 \\
Total trade & US\$100 mil & 41.7 & 20.05 & 19.7 & 22.7 & 22.6 & 23.9 & 28.6 \\
Export & US\$100 mil & 17.3 & 7.4 & 5.6 & 6.5 & 7.3 & 7.8 & 10.2 \\
Import & US\$100 mil & 24.4 & 13.1 & 14.1 & 16.2 & 15.3 & 16.1 & 18.4 \\
Energy & & & & & & & & \\
Coal Production & tons mil & 33.15 & 31.10 & 22.50 & 23.10 & 21.90 & 22.30 & 22.80 \\
Power Generation Capacity & $\mathrm{kWh}$ mil & 7.14 & 7.14 & 7.55 & 7.75 & 7.77 & 7.77 & 7.77 \\
Actual Power Generation & $\mathrm{kWh}$ mil & 2.77 & 2.30 & 1.94 & 2.02 & 1.90 & 1.96 & 2.06 \\
Crude Oil Imports & bbl mil & 18.47 & 8.06 & 2.85 & 4.24 & 4.38 & 4.21 & 3.90 \\
Agricultural \& Fisheries & & & & & & & & \\
Cereals & tons mil & 4.02 & 3.45 & 3.59 & 3.95 & 4.13 & 4.25 & 4.31 \\
(Rice) & tons mil & 1.45 & 1.21 & 1.42 & 1.68 & 1.73 & 1.72 & 1.80 \\
Fishery Products & tons mil & 1.45 & 1.05 & 0.70 & 0.75 & 0.81 & 0.84 & 1.17 \\
Mining & & & & & & & & \\
Iron Ore & tons mil & 8.43 & 4.22 & 3.79 & 4.21 & 4.08 & 4.43 & 4.58 \\
Nonferrous Metals & tons mil & 0.24 & 0.15 & 0.10 & 0.09 & 0.09 & 0.09 & 0.10 \\
Manufacturing & & & & & & & & \\
Steel & tons mil & 3.36 & 1.53 & 1.09 & 1.06 & 1.04 & 1.09 & 1.07 \\
Cement & tons mil & 6.13 & 4.22 & 4.60 & 5.16 & 5.32 & 5.54 & 5.63 \\
Fertilizer & tons mil & 0.89 & 0.68 & 0.54 & 0.55 & 0.50 & 0.42 & 0.43 \\
Synthetic Fiber & tons mil & 0.05 & 0.06 & 0.03 & 0.03 & 0.03 & 0.03 & 0.03 \\
\hline
\end{tabular}

Today, the North Korean economy would not appear to be in good shape. According to the North Korean Yearbook, North Korea's industrial production grew to $102 \%$ in 2001, $112 \%$ in 2002, and $110 \%$ in 2003, respectively (compared to the previous year's production rate). Yet, there is no way for us to infer an "accurate rate of growth in the previous year," because the Yearbook fails to offer any secondary evidence.

In general, at the time of writing North Korea seems to be a failed system. For a long time the regime seems to have been incapable of supplying enough food, energy and any other basics to meet the needs of its people. With the serious shortage of basic necessities, people in North Korea have failed to concentrate on their production activities. Many people in the North have actually left their work places in order to roam around begging for food and engaging a small-time activities at the markets. This, in turn, has caused the production system to deteriorate further. In short, the North Korean system is in a vicious downward spiral.

\section{WHAT ECONOMIC POLICIES HAS THE NORTH KOREAN REGIME ADOPTED SO FAR?}

What then is the essential nature of the economic crisis in North Konnto Korea $_{\text {and }}$ and 
what should be done to resolve it? The North Korean regime argues that the current economic crisis is a product of external factors such as the collapse of the socialist countries and natural disasters, rather than a result of its own systemic failure. The current crisis, the regime argues, is only temporary and problems will be resolved soon (Virtually no one outside the country seems to agree with the regime's argument.).

This does not mean, however, that the regime does not recognize the essential nature of the current economic crisis. Over a long period of time, the North Korean regime has been engaged in economic reforms, although never on a full scale. However, those reforms have failed to produce any visible success.

\section{Policy of Autarky and its Solicitation of Foreign Capital}

The North Korean economy seems to the world's most "autarkic" economy. The North Korean regime has persistently promoted autarky. Autarky is an essential part of its ideology of Juche, which can be roughly translated as "self-reliance." In reality, however, despite all the official pronouncements and propaganda statements, economic policymakers in North Korea have always sought outside assistance in the process of building their economy of self-reliance. To put it differently, the North Korean regime has always been open toward the international community - albeit not on a full scale - since the late 1950s when its socialist economic system was first established.

From the 1953 armistice through the mid-1960s, North Korea was eager to secure sizable inflows of machinery and capital from the "fraternal" communist states. During this period, China and the Soviet bloc were virtually the only sources of foreign capital equipment for North Korea. During the 1960s, however, North Korea's aid and trade relationships with its socialist patrons began to decline, largely due to the impact of the Sino-Soviet schism.

North Korea then tried to switch its economic partners from its socialist patrons to non-Communist countries. In the early 1970s, North Korea executed a strategic turn and began to approach Japan and other western countries for capital goods. For a while, a considerable amount of western equipment entered the country, but it was paid for by hard currency loans. Around 1976, North Korea found itself unable to repay the loans that financed these large purchases. There is an argument as to whether North Korea initially intended to repay these loans or not, but whatever its initial intentions, the North defaulted and has not paid these debts to this day. ${ }^{3}$

Because of its debt problems, North Korea's international trade was largely reduced in volume and once again constrained within the boundary of the Communist bloc. The North, however, did not give up its hopes of acquiring capital goods from western countries. In 1984, North Korea promulgated a Joint Venture Law 
which aimed at attracting foreign capital and technology. In the same year, the North began negotiations for an economic cooperation agreement with the USSR for the years 1986-1990.4

But these efforts proved largely unsuccessful. By June 1990, the Joint Venture Law had managed to succeed in attracting a mere 66 joint venture projects. In addition, in an overwhelming majority of these projects, the "western" side was represented by Chongryon businessmen and companies. 5 By the end of 1991, the North had been successful in concluding only 140 joint venture contracts worth $\$ 150$ million. The economic agreement with the USSR was rendered meaningless by the final crisis and eventual disintegration of the Soviet Union. Moreover, the collapse of the socialist camp in the late 1980s emerged as a decisive factor further aggravating North Korea's economic plight.

To cope with the mounting difficulties North Korea in 1991 announced a plan to designate the Rajin-Sonbong strip along the east coast as a free economic and trade zone. Initially, North Korea was quite aggressive in promoting this scheme, largely because there was no more international socialist market on which it could rely. The North, in other words, desperately sought a substitute for its now vanished socialist market.

At first North Korea appeared to have a strong chance of success. In fact, the North attempted to construct a cargo transit base, processing plants, and a tourist business infrastructure, among others, in the Rajin-Sonbong area. To this ends, the North had planned to invest about $\$ 6.989$ billion in the area, and in the early 1990s, it promulgated about 50 laws and regulations designed to attract foreign investment.

With the Rajin-Sonbong project, however, North Korea soon faced a dilemma, since its two basic needs proved to be contradictory and even mutually exclusive. On the one hand, it was necessary for North Korea to open up its doors in order to cope with increasing economic pressures. On the other hand, however, it needed to tighten political control over its populace in order to protect the existing regime in Pyongyang. Initially, the North attempted to have the best of both worlds. It vigorously approached the West, and particularly the United States and Japan, to attract capital while avoiding interaction with South Korea as much as possible in order to maintain its internal political stability.

For whatever reason, however, the North Korean schemes failed to attract much attention from the western world. The North initially proclaimed its intention of attracting $\$ 3.66$ billion worth of investment into the industrial sector. In early 1996 , however, it adjusted this goal to only $\$ 437$ million, or a mere $12 \%$ of the original target. ${ }^{6}$ The meager scale of these achievements was largely attributable to the poor infrastructure in the Rajin-Sonbong area, as well as the North's general reluctance to institute reforms in its domestic economic system. ${ }^{7}$

When the outside observers almost gave up the possibility of the Rajin-Sonbong project's success, North Korea presented a series oof similar otype lof daig/projects: : 06:57Am 
The North designated Shineuiju as the "Special Administrative District" in September 2002 while Mt. Geumgang and Gaeseong were designated "special district" in October 2002 and November 2002 respectively. In those areas, the "foreign" investors including South Koreans can be relatively free to expand their activities. As of 2005, however, none of these projects can be evaluated as "successful." At the very least, none of them has reached the level of the initial expectations.

In order to attract investment, the North was forced to open up its doors to the outside world and improve relations with developed countries, and particularly with South Korea and the United States of America. No country can successfully pursue economic reform without full scale of market-opening, and North Korea is no exception from this rule. However, it could not persist with this policy for political reasons.

In January 2001, North Korea's leader Kim Jong-il presented the "New Thinking" policy. With the "New Thinking" policy, Kim urged "reforms by approaching issues from a new perspective" while discarding conventional methods. North Korea, in turn, strove to change from "self-reliance" to "new self-reliance" in its economic reform. Kim first announced guidelines for improving economic management in October 2001. These provided the political and theoretical basis for the July 2002 economic reforms. These guidelines stipulate that the basic principle of economic reform is to "obtain maximum profits while maintaining socialist principles." North Korea appears to be currently striving for efficiency in the implementation of economic reforms in various sectors, yet as long as it insists on maintaining socialist principles, these efforts at reform would appear to be ineffectual.

\section{From Prohibition to Tacit Approval of the Market Economy}

The North Korean regime has never admitted, at least officially, that its socialist economy could ever have any kind of difficulty. Yet, the regime realized from the very inception of its socialist economy that it might. On February 8, 1946, the Provisional North Korean People's Committee was organized and on March 5 it promulgated the Land Reform Law. Land reform was completed very quickly by the end of March 1946 or within just 25 days. ${ }^{8}$ On August 10, the People's Committee promulgated a law nationalizing industries, transportation facilities, telecommunication and postal services, banks, and other major businesses. With this law, the regime nationalized 1,034 major industrial enterprises which accounted for $90 \%$ of its industrial capacity.

By then, however, private ownership was safely enshrined in the North - or at least that is what most people in the North believed. Although the land reform law stipulated that the redistributed land was not to be sold, rented, or mortgaged, private ownership of land was maintained. All farmland in 1946 was privately owned, and $100 \%$ of agricultural output was also privately owned. The People's Committee even announced measures to protect the ownership of private enterprises 
in October 1946.

After the Korean War, however, the North Korean regime began the collectivization of agriculture. In 1953, 4.6\% of total agricultural land belonged to state farms and $0.6 \%$ belonged to cooperatives, while $94.8 \%$ belonged to private owners. Private enterprises withered quickly, mainly because they were subjected to government control of the allocation of labor as well as of raw materials, and strict price controls. Some $4 \%$ of all industries were still privately owned in 1953.

By 1958, 92\% of total agricultural land was owned by cooperatives and $8 \%$ by state farms, and all industries were either state owned or collectivized. In January 1959, the regime officially abolished the private ownership of agricultural and industrial properties. This event signaled the arrival of a new stage in the socialist economy of North Korea.

In August 1958, the North Korean regime permitted farmers to use patch farms or small plots of land for private cultivation. Patch farms were not technically the farmers' property. Product from these farms, however, was the property of the farmers and they could dispose it at will. In accordance with "Cabinet Decision No. 140," farmers' markets were also allowed. One or two farmers' markets were designated in each county. These markets could only open 3 times per month, on the 1st, 11 th and 21st days of each month. The prices in these farmers' markets were determined by supply and demand - in other words, in a largely capitalistic way.

The North Korean regime has never been comfortable with either the patch farms or farmers' markets. These vestiges of petit capitalism were merely tolerated by the system. Kim Il-sung defined farmers' markets as "a remnant of the downgrading of capitalism" (Institute for Juche Economics 1985, 367) and argued that markets as well as private patch farms would be abolished as the socialist economy developed (Kim 1969, 467). In reality, however, patch farms and farmers' markets were becoming increasingly important in North Korea. Their existence allowed people to cope with the increasing shortage of consumer goods. Although the regime has never acknowledged it officially, the necessity of these markets was certainly understood by the elite.

In the 1970s, North Korea again undertook certain economic reforms, such as the so-called "three-revolution movement" or revolutions in ideology, technology, and culture. The North attempted to introduce advanced technology from the West and to initiate large-scale trade with the Western world. These reforms were influenced by the detente atmosphere which prevailed around the world after 1970 as well as by China's increasingly pragmatic policies and its emerging success.

However, these efforts produced little practical results for two major reasons. For the North Korean elite, on the one hand the need to safeguard the existing regime was of far greater importance than the need to bring about reforms in the system. Consolidating Kim Jong-il's position as the successor to Kim Il-sung was far more important than any kind of economic reform. Those attempts to reform the domestic economy were also disrupted by the general situation in the 
world markets which had taken a turn which was unfavorable to Pyongyang. The prices of raw materials of North Korean origin dropped substantially, thus depriving Pyongyang of expected income. The oil shock also added to the difficulties of North Korea.

In the 1980s, the North Korean authorities remained to be engaged in reform and even undertook some moderate efforts to open up the country's economy. Although these measures were too meager to be labeled "reforms," the North was serious about adjusting its economic policies to the new realities. In 1981, the regime established an Economic Guidance Committee in each province, and transferred most of the central government's management functions to local authorities, including the vital rights to determine prices. In 1984, the regime introduced a self-accounting system in enterprises, and established a system of complex enterprises which had autonomous powers, including the payment of a bonus dividend to its workers in the following year.

The most striking policy of the 1980s was the tacit approval of the "second economy"9 or underground market activities. In May 1984, the regime mandated the opening of one or two daily markets per county. Soon, three or four daily markets existed in each major city and county. In addition, Kim Jong-il encouraged the farmers and workers to engage in moonlighting activities by initiating "the August 3rd Consumer Goods Production Movement."10 Kim ordered the production of more consumer goods by utilizing whatever materials were available in a given locality. Under this order, various work units were formed in factories, farms, and villages. In order to boost consumer goods production, Kim gave these new work units permission to sell their products freely on the markets. As the economic situation deteriorated, an increasing number of people began to engage in similar activities, not as members of their work units, but on an individual basis.

From 1987, all factories in the countryside were granted a piece of land which was to be divided and distributed among the workers for subsistence farming. Typically, about 50 pyong (approximately 150 sq meters) of land was allocated to each worker. Factories also granted their employees 20 days of leave twice every year. This leave was to be spent farming. More importantly, products from the land could be disposed of at the worker's will. The productivity from these factory subsistence farms far exceeded that of the official farm cooperatives. ${ }^{11}$

Thanks to the regime's economic policies in the 1980s, the second economy in North Korea grew rapidly. More and more people bought their everyday necessities at markets instead of government-run stores, as the public rationing system grew more feeble. ${ }^{12}$ Then, the Soviet Union and the socialist countries of Eastern Europe collapsed from the late 1980s. The collapse of its allies was a shock to the North Korean regime and it had major repercussions on its economic policy.

Under the impact of the Soviet collapse, the regime began to worry about the decline of the socialist values of the populace. In fact, the second economy came to be perceived as a major threat to these values and, hence, to political stability. 
The second economy spread "capitalistic vices" such as individualism, mammonism, and materialism. In the early 1990s, the North Korean regime attempted to establish stricter control over the markets, and authorities began to pay more attention to enforcing the existing regulations. One of their particular concerns was the frequency of market days. Originally farmers' markets were intended to take place once every ten days in rural areas but from the late 1980s, they had become a daily phenomenon. In 1989, the North Korean regime banned illegal private farming, and in 1992 it was proclaimed that all unauthorized markets had to be closed and farmers' markets would be allowed to function only once every 10 days.

These measures, however, were not to last long and were soon reversed. From 1993, even grain, which had been excluded from the market trade before, could be sold on these daily open markets ${ }^{13}$ In addition, the second economy has expanded to the areas of services, foreign exchange, and even housing exchange (Chun 1998, $10)$.

Along the way, the North Korean regime has begun to show some sense of pragmatism through partial acceptance of the market economy. This could pave the way for the gradual acceptance of an open-door-policy aimed at an increase in economic opportunities. North Korean economic policies of this type need to be further analyzed.

\section{HOW CAN THE REGIME CONTINUE TO CONTROL ITS PEOPLE?}

It is widely accepted that the North Korean regime has managed to tame its people such that they obey whatever order is handed down by the authorities. The government has been very successful at political indoctrination. Still, the regime has balked several times in order not to confront its citizens' economic demands.

As we have mentioned above, in 1989 the North Korean government officially banned illegal private farming, and in 1992 it was declared that all unauthorized markets must be closed and farmers' markets would open only once every 10 days rather than every day. In 1993, however, the regime was forced to relax its regulation over these activities due to an aggravated shortage of commodities and food. The government was forced to admit that most people in North Korea eked out an existence by participating in these underground economic activities. Finally, in March 2003, North Korea restructured the informal farmers' markets into general markets, transferred the management rights of state-run stores to various institutions and enterprises at a private level. While reorganizing the traditional farmers' markets into so-called "general markets," North Korea in fact sanctioned transactions according to market prices or princes negotiated between a buyer and a seller.

There are even earlier examples of such flexibility. In 1975, the regime began to run special stores for the exclusive use of foreigners and where only foreign currencies could be used. In 1986, however, it was agreed that anyone with foreign 
exchange could have access to these stores. In 1989, when Pyongyang hosted the World Festival of Socialist Youth and Students, these stores appeared throughout the country. The dramatic increase in the number of these stores was undoubtedly perceived as ideologically dangerous, so in 1992 the regime ordered to close all these stores, except 7 shops in Pyongyang and one in each province. As a consequence, the government began to experience difficulties with foreign exchange, so in 1993 it was decided to increase the number of these foreign currency stores again.

In 1992, the North Korean regime ordered every province and city to organize so-called "Anti-Socialist Groups" (hereafter ASP). With these groups, the regime intended to root out so-called anti socialist criminal activities, such as illegal brewing, embezzlement of government property, theft and the like. These groups consisted of members of the Public Security Ministry (police), the Public Procurator's Office, the Workers' Party, the Socialist Working Youth League and Trade Unions. A typical group in a big plant was composed of 30 persons, and in the border city of Shineuju about 300 officials served in ASPs. But the operation of these groups produced various adverse effects: the group members arrested citizens at random on the pretext that they should undergo investigation for illegal activities in the distant past, or searched company offices or private houses at any time at will. On top of this, the group members began to receive bribes from those who were engaged in illegal businesses, thus producing a chain of corruption. Only those who had no money or power fell victim to these ASP members so in 1993 the regime finally ordered the suspension of the ASPs.

Despite the aggravated economic situation, most people in North Korea have been able to eke out an existence, mainly due to illegal private farming and black market activities of various kinds. Had the regime been really serious in its attempts to crush these activities and not tolerate any kind of illegality, the citizens of North Korea might have revolted against the authorities. In reality, however, the regime had room to maneuver and often stepped back in the face of the people's necessity. This phenomenon can be seen to explain partially why North Korea has not collapsed under the severe economic strain it has been experiencing in recent times.

Ideological indoctrination is the major political means used by the North Korean regime to tame its people, however there would appear to also be some economic means at the regime's disposal. These economic means may be summarized as follows:

Unlike in politics, the North Korean regime has been ready to tacitly negotiate with its people on economic matters wherever necessary. No matter how strongly the regime desired to crush black markets, it decided to retreat and even permitted the markets' continued existence and expansion when it was felt that the people's dissatisfaction with their economic conditions would possibly lead to political instability, if not open revolt. Such a strategy offered some relief to the North Korean people and in turn, functioned as a safety valve, ensuring the North Korean regime's 
political survival.

The increase in power of the second economy ${ }^{14}$ has also significantly altered the North Korean people's values and worldview. It has served to spread a sense of individualism or materialism as well as bribery and corruption. Many North Korean people who had been indoctrinated with the notion of "socialist virtue" are now enslaved by the desire for material gain, though for the most part such gains are impossible without engaging in some kind of illegal activity. Bribes are common in North Korea today. Many North Korean public officials such as party cadres, members of the police and managerial staff routinely collect bribes from those who are engaged in illegal deals. Sometimes these officials themselves are also engaged in illegal activities. Thanks to their illegal incomes and bribes, some public officials can afford to buy expensive goods in the markets, just like "evil capitalists" in a capitalist society, while others starve to death. These market-like relations may produce a small group of quasi capitalists who are striving to supply whatever goods people want to buy and their activities are likely to accelerate a further liberalization of the regime's economic policy in the future.

In short, the role of the North Korean second economy is two-fold and has both short-term and long-term effects. In the short term, it contributes towards easing commodity shortages. Without the second economy, the North Korean regime would be unable to satisfy people's demands for food and basic consumer goods. Under the circumstances, any attempts to crack down on the second economy might lead to popular resistance. The second economy has been functioning as a safety valve for the regime and helps with the amelioration of certain serious economic problems. Thus the second economy helps to protect the North's political system while serving as a relief channel, enabling the people to access food and consumption goods in times of difficulty.

In the long term, however, the impact of the second economy is likely to be negative for the North Korean regime. The second economy is an effective channel for destroying the core value system of socialism. Under its influence, the North Korean people are increasingly inclined to follow individualism and pursue profit rather than practice socialist "virtue." Thanks to the second economy, the people's value system is changing rapidly from socialist to capitalist. The prolonged existence of this second economy is therefore likely to result in undermining the fundamental values of North Korea's society from within.

\section{WHAT WE SHALL DO ABOUT NORTH KOREA IN THE FUTURE?}

Andrew Walder $(1995,1)$ sensibly points out that the two pillars of communist rule are a Leninist party organization and a centralized command economy. In order to understand a communist system, therefore, we need to combine both a political approach and an economic approach. So far, however, only with political 
indoctrination has been cited to explain why North Korea has not yet collapsed under the severe economic strain to which it has been subjected. Without considering its economy, however, we are unlikely to form a wholistic view of North Korea's society.

The North Korean regime has been striving to readjust and improve its economic structure since the 1970s. The regime has sought foreign capital and technology. However, the regime has been attempting to reformulate its economic structure within the strict framework of the existing political system whose survival was its paramount concern, and therefore it has failed to link the domestic economy with the world economy. What the regime has been doing is, on the one hand, to map out policy measures designed to open up its doors, while on the other hand escalating its ideological and political campaigns to prevent the people from being "contaminated" by a capitalist culture which it anticipated would develop as a result of such measures. It is no wonder that, under these conditions, all attempts at reforming met with only limited success at best.

The North Korean regime, however, has negotiated with its people the expansion of its second economy, despite its reluctance to do so. In fact, the regime explicitly defined farmers' markets as remnants of "backward" capitalism which would become extinct as socialism reached a higher stage of development.

It is expected that the ruling hierarchy in North Korea will be able to survive for a considerable period of time, despite the threatening economic crisis. So far in North Korea, the need to safeguard the existing political regime has been given far greater priority than the need to bring about reform. However, the North Korean regime, if it intends to survive, will be compelled to carry out full-scale reforms sooner or later.

Currently, North Korea seems to be in a transitional period in which the regime has apparently not yet decided what to do. The officially sanctioned logic of self-reliance has prevented companies and individuals from obtaining what they need under the current procurement system. Under the circumstances, if the regime adheres to the policy of self-reliance, that policy will be readjusted to encourage market-related activities which the regime can no longer restrict. Private and informal transactions are quickly replacing the vacuum left by the near-collapse of the official economy. Thus, the slogan of Juche or self-reliance is now actually dependent on reform and the continued liberalization of the country.

There are also signs of pressure to open and reform the country from within the North Korean regime. The regime, in fact, has begun a type of moderate open-door-policy which targets an increase in economic opportunities. These actions have nonetheless not yet mounted to a drastic change from the ingrained politico-economic approach and do not signal a large-scale opening up of the economy. These efforts are kept in check by the conservatives who perceive such change as disruptive, as well as by the economic structure itself.

North Korea is in desperate need of foreign assistance and financial aid from 
the international community, including South Korea yet the North continues to provoke tensions with the South. Their provocative gestures towards the South cost the North foreign assistance, but opening to the West and South is also likely to incur the regime considerable political costs in terms of prestige. It is still clear, however, that North Korea needs help from the outside world. In the end, the North must opt for change. The structural pressures caused by the current widespread shortages are simply too great for the regime to withstand. Just how this change will be played out is still unclear.

\section{REFERENCES}

Amnesty International. 2005. North Korea: Briefing on Present Situation. www. reliefweb.int

Cho, Myung-Chul and Zang Hyoungsoo. 1999. The Present and Future Prospects of the North Korean Economy. Seoul: Korean Institute for International Economic Policy

Dong, Young Sueng. 2005. North Korea's Economy and North South Exchange. Korea Economic Trends, Seoul: Samsung Economic Research Institute. 9(25).

Eberstadt, Nicholas. 1998. The DPRK's International Trade in Capital Goods, 1970-1995: Indications from Mirror Statistics. The Journal of East Asian Affairs by The Research Institute for International Affairs 12(1).

Gey, Peter. 2004. North Korea: Soviet-style Reform and the Erosion of the State Economy. Internationale Politik und Gesellschaft, Berlin: Friedrich Ebert Foundation Hilpert, H. G. 2003. Die wirtschaftliche und finanzielle Zukunft Nordkoreas. lecture of 3 July, 2003, Berlin: Friedrich Ebert Foundation.

Institute for Juche Economics. 1985. Dictionary of Economic Terms. 1, Pyongyang: Institute for Social Science in Democratic People's Republic of Korea.

Kim, Il-sung. 1969. Some Theoretical Issues of the Socialist Economy. Collection of Kim Il-sung's Work 23. Pyongyang: The Publishing Company of the Workers' Party of Korea, 1983.

Kim, Young-yoon and Choi Soo-young. 2005. Understanding North Korea's Economic Reforms. Seoul: Korea Institute for National Unification.

Koh, B. C. 1998. The North Korean Political System Under Kim Jong-il: A Comparative Perspective. A presentation paper at the International Conference on North Korea In Transition and Policy Choice: Domestic Structure and External Relations, Seoul, Korea.

Lim, Benjamin Kang. 2005. Food Crisis in N. Korea Worsens, Refugees in China Swell. www.reliefweb.int

Nam, Sung-Wook and Gong Sung-Young, The Effects of the Price and Wage Increases of 2002 on Production and Consumption, unpublished manuscript: 25-26.

Noland, Marcus. 2003. Famine and Reform in North Korea, Institute for International 
Economics, WP 03-5.

North Korean Yearbook (Chosun Jungang Yeonkam in Korean). every year since 1990. Pyongyang: JosunJongang'Tongsinsa.

Rodong Sinmun. 2001. January $1^{\text {st }}$, 2001. Pyongyang: RodongSinmunsa.

Walder, Andrew. 1995. The Quiet Revolution from Within: Economic Reform as a Source of Political Decline. The Waning of the Communist State. Berkeley and Los Angeles: University of California press.

WFP. 2005. World Food Programme Emergency Report 2005 Issued Weekly by the United Nations World Food Programme. Report No. 31/2005.

Yun, Kun-Young. 1997. Privatization of North Korean Economy. A seminar presentation at Institute for Korean Unification Studies, Yonsei University.

\section{ENDNOTES}

1 This announcement was a very meaningful development for North Korea, because for decades Pyongyang had officially insisted that it had had "great harvests" and food surplus every year.

2 Estimates range from 220,000 to 3.5 million deaths in North Korea by starvation. See Noland, 2003, pp. 11-13.

Eberstadt suggests that, considering the North had neglected making timely payments on its ruble-denominated loans from the USSR, the North might be intentionally not repaying its debts to its Western creditors.

4 Officially, it was known as the Intergovernmental Agreement on Mutual Goods Deliveries and Payment for 1986-1990. Though the agreement was signed on February 1986, the relevant negotiation had begun earlier in 1984. See Eberstadt 1998, p. 174.

"Chongryon stands for "General Association of Korean Residents in Japan." It is an organization of pro-North ethnic Koreans residing in Japan.

${ }^{6}$ Namgoong Young, "The Limits of North Korea's Possible Economic Opening: With a Focus on Its Policies regarding the Free Economic and Trade Zone." Unification Economy, pp. 50-77.

The North's nuclear issue and the military tension on the Korean peninsula have also been acted as a deterrent to foreign investors.

${ }^{8}$ With the land reform law, the People's committee confiscated about one million jungbo or very close to one million hectares of agricultural land and 3,433 thousand jungbo of forest land and redistributed 98.1 percent of the confiscated agricultural land to farm laborers, tenant farmers, and small farmers free of charge. For more information, see Kun-Young Yun, 1997.

"The second economy" in this paper refers to all economic activities which occur outside the planned state-run economy of a socialist country, while "the first economy" covers the planned sector. Though this second economy is not a phenomenon unique to North Korea, the fact that it is booming today does require attention.

${ }_{11}^{10}$ The name implied that this movement began on August $3^{\text {rd }}, 1984$.

${ }^{11}$ Hong-Tack Chun, "The Second Economy and Economic Reforms in North Korea"; Jae-Jean Suh, "Economic Origins of Socio-Political Decline in North Korea," presentations at the International Conference on North Korea In Transition and Policy Choice: Domestic Structure and External Relations, Seoul, Korea, 1998.

${ }^{12}$ Professor Lee Young-hwa, an ethnic Korean residing in Japan, said that in the early 1990s people in North Korea were buying 80 percent of their daily goods from black markets. He had lived in North Korea for 8 months in 1991 as a research fellow at the North Korean Science Academy. See Lee Young-hwa, Pyongyang: A Night of Secret Meeting (Pyongyang Bimilziphoeae Pam in Korean), Seoul: Dong-A Publishing Company, 1994.

${ }^{13}$ Naewoe Press, General Data on the Current Situation of North Korea (BukhansilsangJonghapZaryozip in Korean), Seoul: Naewoe Press, 1995, pp. 71-72.

${ }^{14}$ Second economy, also called "parallel economy," or "shadow economy," is actually found not only in North Korea but also in every socialist country. In socialist countries, second economy is operated partly independently and partly interweave together with the state-operated economy. Virtually all products which were otherwise unavailable were to be found in the "second economy." For more information, see Gey (2004). 